\title{
Prezentacje
}

\section{Nadal trwa: trauma i pamięć I wojny światowej}

Ross J. Wilson

TEKSTY DRUGIE 2018, NR 4, S. 218-235

DOI: $10.18318 /$ td.2018.4.14

\section{Potoczna pamięć I wojny światowej: Australia, Wielka Brytania i Kanada}

Od momentu wybuchu aż po dzień dzisiejszy I wojna światowa rzuca długi cień. Wśród walczących niegdyś narodów Australii, Wielkiej Brytanii i Kanady konflikt trwający w latach 1914-1918 zyskał niemal mityczny status'. Nawet sama wzmianka o toczonych w tym okresie bitwach - nad Sommą, pod Vimy czy o Gallipoli - zdaje się wywoływać w tych narodach niemal automatycznie obrazy zniszczonych i obróconych w ruinę krajobrazów, cierpiących żołnierzy, którzy stawiają opór kolejnym falom uprzemysłowionych działań wojennych, jak również intensywne uczucia litości, smutku, gniewu i narodowej dumy². Tak przedstawia się „potoczna pamięć” tego

1 P. Fussell The Great War and Modern Memory, Oxford University Press, Oxford 1975, s. 5; J. Vance Death So Noble: Memory, Meaning and the First World War, University of British Columbia Press, Vancouver 1997, s. 7; J. Winter Sites of Memory, Sites of Mourning: The Great War in European Cultural History, Cambridge University Press, Cambridge 1992, s. 6.

D. Todman The Great War: Myth and Memory, Sutton, Stroud 2001; A. Thomson Anzac Memories: Living with the Legend, Oxford University Press, Oxford 1994.

Ross J. Wilson profesor, historyk i archeolog, wykładowca w Instytucie Historii na Uniwersytecie w Chichester. Interesują go relacje między żołnierzami a kulturą materialną na froncie zachodnim, dyskursy upamiętniania, a także historia muzeum i pojęcie dziedzictwa narodowego. Ostatnio opublikował New York and the Great War: Shaping an American City (2014). Kontakt: rossjwilson@gmail.com 
konfliktu, definiowana jako ogólne postrzeganie wojny właściwe danej populacji, wyłaniające się w obrębie tradycji i kultury, które sytuuje się w kontraście do praktyk poddanego akademickiemu rygorowi zawodowego zgłębiania „historii”"3. Ów kontrast między historią a pamięcią I wojny światowej stał się szczególnie ostry wśród narodów anglojęzycznych wspierających armię brytyjską. W istocie, $\mathrm{w}$ tych społeczeństwach samo wspomnienie wojny 1914-1918 spowija smutek i sentymentalizm, uważany przez badaczy za niemal nie do pokonania ${ }^{4}$.Ten powszechny sposób wspominania działań wojennych stał się przedmiotem surowej - acz może celnej - krytyki. Obrazy „szczurów, gazu, błota i krwi" pogłębiają szeroko rozpowszechnione wyobrażenie wojny, jako krwawego i gwałtownego konfliktu, który doprowadził do śmierci setek tysięcy ludzi i wywarł współmierny ze skalą zniszczeń wpływ na pogrążone w smutku, pozostawione w ojczyźnie rodziny ${ }^{5}$. Właśnie ta potoczna pamięć I wojny światowej, którą przypisuje się jednostkom, grupom i wspólnotom funkcjonującym w ramach wspomnianych już wcześniej narodów, stała się w ostatnich trzech dekadach przedmiotem ciągłej oceny historyków.

Spora grupa prac badawczych w Australii, Wielkiej Brytanii i w Kanadzie ukazuje, jak można kwestionować potoczną pamięć I wojny światowej ${ }^{6}$. Rewizjonistycznie nastawieni historycy starają się dokonać ponownej oceny batalii, wychodząc poza utrwalone tropy rozczarowania i rozpaczy. Bardziej niż na obrazach oddziałów doświadczających grozy i brutalności wojennej zawieruchy badania koncentrują się na poczuciu braterstwa, lojalności i determinacji w żołnierskich szeregach. Niektórzy historycy ukazują wręcz możliwość przeżywania przyjemności podczas wojny oraz ochoczego udziału żołnierzy we wszystkich aspektach służby wojskowej, włącznie z zabijaniem walczących po stronie wroga ${ }^{7}$. Choć pamięć potoczna skupia się na wojnie jako na marnotrawieniu życia - a elitę polityczną i wojskową postrzega się jako grupę wspierającą nierozważną taktykę mającą na celu przedarcie się

3 Popular Memory Group i in. Popular Memory: Theory, Politics, Ethics, w: Making Histories. Studies in History-Writing and Politics, ed. by R. Johnson, G. McLennan, B. Schwartz, D. Sutton, Routledge, London 1982, S. 205.

4 B. Bond The Unquiet Western Front, Cambridge University Press, Cambridge 2002.

5 G. Corrigan Mud, Blood and Poppycocks: Britain and the First World War, Cassel, London 2003.

6 G. Sheffield Forgotten Victory. The First World War - Myths and Realities, Headline, London 2001; G. Corrigan Mud, Blood and Poppycocks...; D. Todman The Great War...

7 J. Bourke An Intimate History of Killing: Face-to-Face Killing in Twentieth-Century Warfare, Granta Books, London 1999. 
przez linię okopów przeciwnika - historycy wojskowości badają działania wojenne jako sukces operacyjny. Ich studia pokazują, że w manewry wojskowe z powodzeniem włączano nowe technologie, co nie tylko ujawniało świadomość warunków panujących na polu bitewnym, ale także zapewniło w 1918 roku ostateczne zwycięstwo armii Imperium Brytyjskiego i jej sojuszników. Ów sukces podejmowanych przezeń działań militarnych to fundamentalny argument wysuwany przez rewizjonistycznie nastawionych historyków. Służy on podważeniu interpretacji wojny w kategoriach bezsensu i daremności, które wpłynęły na odczytywanie zawieszenia broni w listopadzie 1918 roku jako „zapomnianego zwycięstwa”.

Prace te badają również zafałszowaną naturę potocznej pamięci konfliktu, jaka funkcjonuje wśród narodów, które uczestniczyły w walkach. Prowadzone analizy wykazują, że przekonania dotyczące I wojny światowej nie stanowią wytworu historii, lecz dowodzą akceptacji określonych form kulturowych. Powojenne pamiętniki, powieści, filmy i programy telewizyjne przedstawiają wojnę czy to za pośrednictwem scen ukazujących pola bitewne wraz z żołnierzami znoszącymi po stoicku swe cierpienie, czy też poprzez funkcjonujące poza polami bitew, dotknięte nerwicą frontową ofiary; przez historyków postrzegane są przy tym jako źródło rozpowszechnionych błędnych wyobrażeń konfliktu. Uważa się, że wspomniane środki przekazu promują jego ograniczone wizje, koncentrując się na szoku i emocjach jako cynicznych sztuczkach służących przyciągnięciu uwagi publiczności ${ }^{9}$. Niezależnie od tego, czy chodzi o kanadyjski film Paula Grossa Passchendaele. Trzecia bitwa (reż. Paul Gross, Damberger Film and Cattle, Co., 2008), klasyczną brytyjską komedię telewizyjną Czarna żmija (reż. Richard Boden, BBC, 1989) czy ikoniczny australijski film Gallipoli (Australian Film Commission, 1981) w reżyserii Petera Weira, zawarte w nich sposoby obrazowania wojny stanowią przedmiot krytyki historyków, którzy uznają te ograniczone i oparte na kliszach sposoby ekspresji za siłę napędową publicznych nieporozumień. Krótko mówiąc, potoczne postrzeganie konfliktu ma charakter „zmediatyzowanej pamięci". Owa potoczna pamięć to również odrębny powojenny konstrukt, wyłaniający się nie tyle z krajobrazu samych pól bitewnych, ile z reprezentacji I wojny światowej powstałych po roku 1918. Na przykład w Wielkiej Brytanii to twórczość wspomnieniowa Siegfrieda Sassoona, Edmunda Blundena

8 G. Sheffield Forgotten Victory...

9 S. Badsey Blackadder Goes Forth and the 'Two Western Fronts' Debate, w: Television and History, ed. by G. Roberts, P.M. Taylor, University of Luton Press, Luton 2001, s. 113-125. 
i Roberta Gravesa ukształtowała obraz wojny jako ćwiczenia z daremności i rozczarowania, skutkujące tragiczną śmiercią setek tysięcy młodych ludzi ${ }^{10}$. Ten pamięciowy konstrukt podlega ocenie rewizjonistycznie nastawionych krytyków, którzy pokazują, że potoczne sposoby upamiętniania wojny w tym okresie - a w gruncie rzeczy aż po dzień dzisiejszy - ukazują więcej na temat tych, którzy angażują się w proces upamiętniania, niż na temat samych wydarzeń rozgrywających się między rokiem 1914 a 1918.

Niemniej jednak badacze wiedzeni pragnieniem podkreślenia charakteru tej związanej z pamięcią potoczną „wynalezionej tradycji” często lekceważą czy wyśmiewają znaczenie, jakie ten rodzaj pamięci niesie ze sobą dla kultywujących ją społeczeństw. Mimo że pamięć potoczna przyjmuje zbliżoną formę we wszystkich trzech narodach - ogniskując się wokół brutalności i grozy traumy wojennej - sposoby jej wykorzystywania mocno się różnią. W Australii potoczną pamięć wojny zakorzeniono w pojęciach narodowej tożsamości. Upamiętnienie ofiary poniesionej przez Australijski i Nowozelandzki Korpus Wojskowy (ANZAC) uznaje się za narodowy mit założycielski, pozwalający zaznaczyć własną odrębność i odmienność od Wielkiej Brytanii jako kolonialnego zwierzchnika"1 . Uważa się, że to w gronie mężczyzn tworzących ów korpus wojskowy wyłoniły się cechy definiujące charakter narodowy: siła, wytrwałość, antyautorytaryzm, partnerstwo i poczucie humoru. WWielkiej Brytanii pamięć potoczna stanowi równie istotny czynnik formowania tożsamości. Obrazu cierpiącego żołnierza w okopach używa się do mobilizacji różnych rodzajów politycznej tożsamości, jako że grupy lewicowe wykorzystują przekonanie o niekompetencji oficerów wywodzących się z wyższych klas społecznych, wysyłających na śmierć w bezsensownych atakach kolejne zastępy mężczyzn z klas pracujących, by podkreślić nadużycia władzy i lekceważenie społeczeństwa okazywane przez rządzących ${ }^{12}$. Również w Kanadzie I wojna światowa służy jako środek do portretowania charakteru narodowego. Służba i oddanie kanadyjskich oddziałów wojskowych, zwłaszcza na polach bitewnych pod Beaumont Hamel i Vimy Ridge, wryły się w potoczną świadomość jako przykłady romantycznego indywidualizmu, narodowego heroizmu i zwycięstwa par excellence ${ }^{13}$. Wobec tego, choć pamięć

\footnotetext{
10 B. Bond The Unquiet Western Front..., s. 5-7.

11 A. Thomson Anzac Memories..., s. 9.

12 R. Wilson The Trenches in British Popular Memory , "Interculture" 2008 No. 5.2, S. 109-118.

13 J.Vance Death So Noble..., s. 5-6.
} 
potoczna stała się przedmiotem debaty i celem rewizji, komentatorzy przeoczyli funkcję i użyteczność takiego sposobu upamiętniania.

Tego rodzaju perspektywa staje się szczególnie znacząca w rozważaniach dotyczących trwania pamięci potocznej. Mimo podejmowania przez badaczy prób kwestionowania szeroko rozpowszechnionych sposobów postrzegania wojny w Australii, Wielkiej Brytanii i Kanadzie to właśnie obraz „błota, krwi, szczurów i gazu" nadal pozostaje obrazem wiodącym. Nie da się umniejszyć potrzeby upamiętniania pól bitewnych I wojny światowej jako zdewastowanej areny, na której toczył się zindustrializowany konflikt i na której pojedyncze jednostki znosiły przerażające męki wśród zgiełku artylerii i karabinów maszynowych, służąc jednocześnie rozmaitym celom wyznaczanym w obrębie konkretnych zbiorowości. W rezultacie, zamiast podejmować próby podważenia owych publicznych sposobów postrzegania, należałoby zastanowić się, dlaczego pamięć potoczna skupia się na traumie tej wojny. W tym kontekście kwestia reprezentacji kulturowych nabiera najwyższej wagi. Chociaż powieści, filmy i programy telewizyjne stały się już przedmiotem analizy jako źródła pamięci, być może trafniej oddają one szeroko rozpowszechnione przekonania dotyczące wojny ${ }^{14}$. Niektóre reprezentacje konfliktu przedkłada się nad inne, ponieważ uważa się, że wyrażają "prawdę” o wojnie. Prawda ta obejmuje grozę wojny; to właśnie trauma, którą komunikują i cenią sobie konsumenci wspomnianych form kultury. W gruncie rzeczy, choć kulturowe reprezentacje I wojny światowej w Australii, Wielkiej Brytanii i Kanadzie są tworzone i wykorzystywane w odmiennych celach, łączy je ukazywanie horroru i brutalności wojny.

By ocenić ten wspólny trop, można wykorzystać teorie związane z traumą kulturową, ale nie po to, by śledzić, w jaki sposób reprezentacje wojny kształtowały pamięć potoczną, ale by przekonać się, jak powieści, film i telewizja umożliwiły komunikowanie traumy, która wyraża się w takiej właśnie pamięci ${ }^{15}$. Podejście tego rodzaju odrzuca przeświadczenie, że jednostki i wspólnoty to bierni konsumenci mediów, a przyjmuje, że tego typu reprezentacje stanowią ramy pozwalające aktywnym aktorom społecznym (agents) podtrzymywać określone wizje przeszłości ${ }^{16}$. Pojęcie

J. Wertsch Voices of Collective Remembering, Cambridge University Press, Cambridge 2002, s. 17. University Press, Cambridge 2001, s. 6. 
traumy kulturowej okazuje się w tym wypadku szczególnie użyteczne, umożliwia bowiem przyjęcie alternatywnego spojrzenia na pamięć potoczną, traktowaną nie jako wyraz niezrozumienia przeszłości, lecz jako żywy element tożsamości: „Trauma kulturowa ma miejsce wówczas, gdy członkowie zbiorowości czują, że poddani zostali straszliwemu wydarzeniu, pozostawiającemu nieusuwalne ślady na ich grupowej świadomości, na zawsze naznaczającemu ich wspomnienia oraz zmieniającemu ich przyszłą tożsamość w fundamentalny i nieodwołalny sposób". ${ }^{17}$ Idąc w ślad za diagnozą Breuera i Freuda dotyczącą możliwości kształtowania jednostek przez traumę ${ }^{18}$, badacze wykorzystują to podejście, by pokazać użyteczność „traumy” jako trybu analizy ${ }^{19}$.Tym sposobem trauma tworzy sposób komunikowania wspólnotowych koncepcji poczucia tożsamości zarówno jednostkowej, jak i zbiorowej. Odnosi się to także do prac Petera Novicka, który ocenił współczesną koncentrację na kwestiach „bycia ofiarą" i traumy, postrzeganych jako środki określające tożsamość, w opozycji do klasycznego zainteresowania problematyką odwagi i zwycięstwa ${ }^{20}$.

Trauma kulturowa jest definiowana za pośrednictwem rozmaitych środków przekazu; od powieści i filmów po pomniki i praktyki upamiętniania. Znaczenie tych reprezentacji czy działań polega na ich zdolności do podtrzymywania poczucia szoku, bolesnej straty i cierpienia ${ }^{21}$. Podobieństwa występujące w ich ramach i powtarzające się w ich obrębie motywy wskazują na istnienie wspólnych sposobów postrzegania określonego wydarzenia historycznego oraz pragnienie podtrzymania i utrwalenia wpisanych w nie znaczeń. W rezultacie prowadzi to do ponownego potwierdzenia tego, co współcześni odbiorcy uznają już za oczywiste, a następnie wymaga od nich przyjęcia pozycji świadka określonej traumy; przeniesienia prawdy o przeszłości w teraźniejszość przez świadczenie o jej znaczeniu. Formy kulturowe funkcjonują jak środki pozwalające skupić uwagę na historycznym bólu

17 J.C. Alexander Trauma kulturowa i tożsamość zbiorowa, w: Znaczenia społeczne. Studia z socjologii kulturowej, przeł. Stanisław Burdziej, Jacek Gądecki, Nomos, Kraków 2010, s. 195.

S. Freud, J. Breuer Studia nad histeriq, przeł. R. Reszke, Wydawnictwo KR, Warszawa 2008, s. 11-21.

C. Caruth Unclaimed Experience: Trauma, Narrative, History, The Johns Hopkins University Press, Baltimore 1996, s. 17.

P. Novick The Holocaust in American Life, Houghton Mifflin, Boston 2000, s. 214.

N. Smelser Psychological Trauma and Cultural Trauma, w: Cultural Trauma and Collective Memory..., s. 31-32. 
i niepokoju. W istocie te formy przekazu, które umożliwiają komunikację traumy, wynosi się ponad inne i umieszcza w związku z tym w szerszej symbolicznej sieci wespół z towarzyszącymi im znaczeniami. Idąc tym tropem, potoczną pamięć I wojny światowej w Australii, Wielkiej Brytanii i Kanadzie można postrzegać w kontekście traumy kulturowej. Owa pamięć potoczna nie wywodzi się z medialnych reprezentacji, to raczej owe reprezentacje odzwierciedlają traumę, którą komunikuje się w ramach pamięci potocznej.

Poprzez ocenę najnowszych powieści oraz produkcji filmowych i telewizyjnych niniejszy artykuł ukazuje sposób, w jaki trauma staje się podstawowym aspektem wspomnianych środków przekazu ze względu na praktykę wykorzystania traumatycznej przeszłości do poruszania problematyki tożsamości w czasach współczesnych. Aby to udowodnić, posłużę się przykładami z okresu po roku 1998, kiedy obchody 80. rocznicy zakończenia wojny postrzegano jako zachętę dla opinii publicznej do zainteresowania się kwestiami traumy wojennej, co miało mieć wyraźne przełożenie na mechanizmy narodowej, regionalnej i politycznej identyfikacjii ${ }^{22}$. Takie koncepcje tożsamości tworzy się za sprawą określonych elementów pojawiających się w ramach kulturowych reprezentacji wojny. Na potrzeby tego studium można je uporządkować w następujący sposób:

- cierpienie żołnierzy - ukazanie oddziałów wojskowych przeżywających udrękę, alienację i rozczarowanie wojną

- spustoszone pola bitewne - obrazowanie przedstawiające piekielne, rozdarte wojną krajobrazy, których mieszkańców dopada wojenna zawierucha

- perspektywa świadka - dostarczenie punktu widzenia, dzięki któremu odbiorcy przyjmują na siebie konkretne brzemię pamięci

Powyższe elementy tworzą podstawową charakterystykę reprezentacji I wojny światowej w rozmaitych środkach przekazu. Choć badacze podkreślają, że dobrze znane sceny ukazują kliszowy charakter potocznej pamięci wojny 1914-1918, ich podejście pomija to, w jaki sposób owe powtarzające się elementy umożliwiają komunikowanie i podtrzymywanie poczucia traumy ${ }^{23}$.

S. Audoin-Rouzeau, A. Becker 14-18, Understanding the Great War, trans. C. Temerson, Hill and Wang, New York 2002, s. 5.

23 E. Hanna The Great War on the Small Screen: Representing the First World War in Contemporary Britain, Edinburgh University Press, Edinburgh 2009. 
W tej perspektywie obrazy służące utrwalaniu traumy w Australii, Wielkiej Brytanii i Kanadzie jawią się nie tyle jako cyniczny wytwór kapitalistycznego przemysłu rozrywkowego, ile jako przejaw charakteryzującego szersze kręgi społeczne pragnienia, aby nadal przedstawiać przeszłość w taki właśnie sposób.

\section{Cierpienie żołnierzy}

Wyrażanie cierpienia w ramach reprezentacji I wojny światowej jest najbardziej wyraźnym aspektem twórczości filmowej, telewizyjnej i powieściowej, która odnosi się do konfliktu 1914-1918. Rzeźbiarskie, tekstowe czy wizualne sposoby ukazywania ciał udręczonych wojną żołnierzy to zauważalny wymiar jej współczesnych przedstawień. Po 1998 roku pojawił się jednak odrębny obszar zainteresowania jednostkowym bólem i statusem „ofiary”. Jego obecność wyraża się za pośrednictwem rozmaitych mediów w Australii, Wielkiej Brytanii i Kanadzie. Na przykład brytyjski film Okop (reż. William Boyd, Arts Council of England, 1999) koncentruje się na doświadczeniu odosobnienia u żołnierzy stacjonujących na pierwszej linii frontu tuż przed kolejnymi działaniami podejmowanymi 1 lipca 1916 roku, w katastrofalnym dniu rozpoczynającym bitwę nad Sommą. Bohaterowie filmu, w tym zaledwie szesnastoletni protagonista, ukazani są w brudnych okopach, w których towarzyszy im wszechobecny lęk przed śmiercią. Obojętność elity wojskowej i społecznej staje się w tym filmie wyczuwalna, podobnie jak brutalna siła wojny, dająca o sobie znać w miarę jak żołnierze pod huraganowym ostrzałem tracą zdrowie i życie. Całość filmu rozgrywa się w tragicznych okolicznościach, ujęta w ramy nieuchronnego żołnierskiego losu, kiedy rozkaz ruszenia poza linię okopów przynosi w kulminacyjnych scenach śmierć ostatnim członkom oddziału. Cierpienie bohaterów, zarówno fizyczne, jak i psychiczne, stanowi clou całego obrazu, w którym głównym bohaterem jest nieletni: jego wiek przydaje siły poczuciu upokorzenia i smutku, jaki pod koniec filmu wywołuje jego zgon.

Temat cierpienia można zauważyć również w brytyjskim horrorze Dolina cieni (reż. Michael Bassett, Apollo Media, 2002) oraz filmach telewizyjnych Wszyscy ludzie króla (reż. Julian Jarrod, BBC, 1999) i Mój syn Jack (reż. Brian Kirk, Ecosse Films, 2007). W każdym z nich z żołnierzy brytyjskich czyni się ofiary; w pierwszym zostają oni porzuceni, by umrzeć w wyniku działania jakiejś złowrogiej, nadnaturalnej siły, w dwu pozostałych giną w związku ze "starym kłamstwem" patriotyzmu i poświęcenia. Cierpienie żołnierzy jest także najważniejszym elementem australijskiego filmu Broken Sun (reż. Brad 
Haynes, JackaFilms, 2008), w którym straumatyzowany były żołnierz ANZAC spotyka podczas II wojny światowej zbiegłego na odludzie japońskiego więźnia wojennego. Doświadczenia australijskiego żołnierza ukazane zostały w sekwencji flashbacków, a brutalność pól bitewnych I wojny światowej nadaje bohaterowi status „ofiary”, który jest porównywany z sytuacją internowanego Japończyka. Bohater ujawnia jednak siłę, hart i wytrwałość, mające z założenia stanowić charakterystyczną cechę typowego australijskiego żołnierza, mimo przeżytej traumy. Podobne poczucie poświęcenia przenika kanadyjski film Passchendaele. Trzecia bitwa (reż. Paul Gross, Damberger Film and Cattle, 2008). Jego bohater przeżywa horror wojny we Francji tylko po to, by wrócić do domu i dać się wykorzystać do przyspieszenia kampanii werbunkowej w Kanadzie. Po ponownym przyłączeniu się do armii, bohater mimo śmiertelnych ran na własnych plecach wynosi z pola bitwy towarzysza, który po eksplozji pocisku wygląda jak ukrzyżowany. Chrześcijańskie obrazowanie tej sceny podkreśla charakter wojennego cierpienia, które staje się wyższym rodzajem poświęcenia. W efekcie trauma wojenna została ukazana w chwili narodowej tragedii.

Problem cierpienia i ofiary został trafnie wykorzystany do krytyki Okopów (reż. Dominic Ozanne, BBC, 2002), telewizyjnego programu typu reality wyemitowanego przez Brytyjską Korporację Nadawczą (BBC). W jego ramach grupa młodych mężczyzn została zrekrutowana, przeszła trening wojskowy, a następnie znalazła się w zrekonstruowanym systemie okopów, by „ponownie przeżyć" to, czego doświadczyli ich przodkowie. Programowi temu stawiano pytania o wyczucie smaku i przyzwoitości, gdyż uznano za niemożliwe odtworzenie unikalnego cierpienia żołnierzy uczestniczących w wojnie 1914-1918. Dla kontrastu The Great War (Wielka Wojna, reż. Brian McKenna, Canadian Broadcasting Corporation, 2008) program telewizyjny Kanadyjskiej Korporacji Nadawczej (CBC) ${ }^{24}$, spotkał się ze znacznie cieplejszym przyjęciem ze względu na zaangażowanie potomków żołnierzy doby I wojny światowej w odtwarzanie scen bitewnych, w pielgrzymki na cmentarze i miejsca pamięci oraz ich udział w rekonstrukcji wydarzeń opisanych w wojennych listach i pamiętnikach. Tym sposobem traumę wojenną przeżyto ponownie w teraźniejszości; została wywołana i doświadczona z myślą o współczesnej kanadyjskiej publiczności, by podtrzymać poczucie szoku i bolesnej straty. Podobnie było w przypadku Australians at War (Australijczyków na wojnie, reż. 
Geoff Burton, Australian Broadcasting Corporation, 2001) ${ }^{25}$, Australijskiej Korporacji Nadawczej (ABC), serialu zgłębiającego wpływ działań wojennych na naród, który koncentrował się na udziale obecnego pokolenia Australijczyków w relacjonowaniu zapisków z listów i pamiętników australijskich żołnierzy stacjonujących pod Gallipoli. Relacje te podkreślały „,rozpacz, trwanie i grozę" kampanii dardanelskiej, a te podano publiczności jako sposób głoszenia chwały i znaczenia tamtej udręki dla całego narodu: „«Who’ll come a-fighting the Kaiser with me»" [Kto stanie ze mną do walki z Cesarzem] ${ }^{26}$ przenosi na ekran Australię, o której zapomnieliśmy lub której po prostu nie znaliśmy - dzięki temu pozwala się nam wierzyć, że była to Australia, którą nadal winniśmy kochać (Australians at War).

Ten nacisk na tragedię żołnierzy jest szczególnie wyraźny w programach towarzyszących obchodom 9o. rocznicy zaprzestania działań wojennych. Na przykład film dokumentalny BBC The Last Day of World War One (reż. John Hayes Fisher, British Broadcasting Corporation, 2008) ujawnił osobistą historię żołnierzy poległych w bitwie już po podpisaniu rozejmu 11 listopada 1918 roku. Prezenter programu Michael Palin, który podzielił się rodzinną historią straty poniesionej przez jego krewnych podczas wojny, opisał życie i śmierć zabitych w jej ostatnim dniu, przeprowadziwszy wywiady z żyjącymi członkami ich rodzin. Trauma wojny została w ten sposób wyodrębniona jako fenomen współczesny, przeżywany i odczuwany w teraźniejszości. Podobnie w Australii, Specjalny Serwis Radiofonii i Telewizji (SBS) wyemitował film dokumentalny Not Forgotten (reż. Jane Jeffes, Firefly Productions, 2008). Program z narracją Marka Lee - znanego z głównej roli w Gallipoli z 1981 roku, kultowym filmie o australijskich i nowozelandzkich żołnierzach - zawierał relacje wojskowych i ich rodzin, podawane w miarę zgłębiania doświadczeń zaciągu, służby wojskowej i żałoby. Dzięki temu ogromnego znaczenia nabrało poczucie cierpienia i poświęcenia. Niemniej jednak założeniem programu było powtórzenie miejsca traumy w świadomości narodowej, zbadanie „spuścizny smutku, straty i pamięci; sprawienie, by ci ludzie nie zostali zapomniani".

Utrwalanie wstrząsu związanego ze skalą strat i nieszczęść w okresie wojny to rzecz oczywista. Przez obraz cierpiących żołnierzy przywołuje się

25 Australians at War. ABC. http://www.australiansatwar.gov.au/television/index.html (12.01.2002).

26 Słowa anonimowej parodii australijskiej piosenki Waltzing Matilda Andrew Bartona „Banjo" Patersona, które posłużyły za tytuł drugiego odcinka pierwszej serii Australians at War [przyp. tłum.] 
historyczną traumę. Jednak funkcja tej traumy jest odmienna w każdym z opisywanych społeczeństw. WWielkiej Brytanii ból i cierpienie żołnierzy w okopach traktuje się jak świętość, jednakże taka pozycja jako exemplum cierpienia może być uruchamiana w rozmaitych celach. Wykazanie związku z traumą prowadzi do powstania szeregu regionalnych, narodowych i politycznych identyfikacji ${ }^{27}$.Związek z historyczną traumą ma legitymizować poczucie tożsamości, indywidualnej lub zbiorowej. Istotnie, szkockie i walijskie oddziały pamięta się ze względu na poniesione przez nie straty; lewicujący politycy upamiętniają poświęcenie klasy robotniczej, a konserwatyści wychwalają narodowy hart ducha i służbę na polach bitewnych ${ }^{28}$. W Kanadzie i Australii poczucie ofiary poniesionej w czasie Wielkiej Wojny to zjawisko formacyjne, poprzez które definiuje się charakter narodowy. Chociaż trauma może służyć wykluczaniu - polegającym na wyeliminowaniu innych z narracji narodowej poprzez uznanie traumy za decydujący moment dla funkcjonowania państwa - stanowi ona także środek organizowania tożsamości w opozycji do władzy ${ }^{29}$. Medialne reprezentacje pól bitewnych nie składają się na sposób postrzegania cierpienia ani nim nie manipulują; odzwierciedlają traumę, która jest już w społeczeństwie obecna, a bywa wykorzystywana przez współczesne wspólnoty do legitymizowania poczucia przynależności i tożsamości.

\section{Opuszczone pola bitewne}

Stałym elementem Wielkiej Wojny, który powtarza się w różnych obecnie stosowanych środkach przekazu, są zdewastowane krajobrazy pól bitewnych. Żołnierze to ofiary w teatrze wojny, podlegające przerażającym procesom uprzemysłowionej walki. Obrazy rozdartych wojną, pokrytych gruzem pól bitewnych - oparte na połączeniu żywych i umarłych rodem z innego świata - podkreślają cierpienie tych, którzy odbywali służbę na takiej arenie. $\mathrm{Na}$ przykład kanadyjska powieść Three Day Road (2005) Josepha Boydena ${ }^{30}$, obfitująca w sceny grozy i traumy, ukazuje losy weterana z plemienia Kri, który próbuje uporać się ze swoimi wojennymi przeżyciami. Śmierć, zniszczenie

27 R. Wilson The Trenches in British Popular Memory...

B. Bond The Unquiet Western Front...

29

A. Thomson Anzac Memories: Living with the Legend, Oxford University Press, Oxford 1994;

G. Seal Inventing Anzac: The Digger And National Mythology, University of Queensland Press, St. Lucia 2004.

30 J. Boyden Three Day Road, Toronto, Penguin 2005. 
i brutalność wojny kontrastują w powieści z plemiennymi praktykami Kri, realizowanymi w harmonii z naturą. Front zachodni przedstawiony jest jako miejsce odczłowieczania, przemieniające innego przedstawiciela plemienia w mordercę, który nawiedza pola bitewne, by skalpować wrogów, co jego dowódcy każe zauważyć, że to zwyczaj „jak u waszych pogańskich przodków"31. Owo wyniszczenie krajobrazu przez wojnę, prowadzące do degeneracji i wiktymizacji jednostki, pojawia się w innych współczesnych powieściach wojennych. W książce dla młodzieży Private Peaceful (2003) brytyjski pisarz Michael Morpurgo ${ }^{32}$ szczegółowo opisuje perypetie bohatera, Thomasa Peacefula, w okopach na froncie zachodnim. Śmiercionośne, ponure pola bitew zamieniają się w miejsce udręki bohatera i jego przyjaciół, kiedy ludzie giną zarówno wskutek palby karabinów maszynowych wroga, jak i wystrzałów plutonu egzekucyjnego armii brytyjskiej, który za odmowę wykonania rozkazu wydanego podczas natarcia wykonuje wyrok na towarzyszu broni Thomasa. Akcja powieści rozgrywa się tuż przed początkiem bitwy nad Sommą, która nieuchronnie doprowadzi do śmierci szeregowca Peacefula. Ukazanie krajobrazu wojennego jako zrujnowanej, opuszczonej i tragicznej areny, gdzie śmierć staje się nieunikniona, ponownie przyczyni się do wzmocnienia poczucia wiktymizacji i cierpienia związanego z konfliktem. Zabieg ten podtrzymuje poczucie traumatycznego doświadczenia, właściwe I wojnie światowej w Australii, Wielkiej Brytanii i Kanadzie.

W społeczeństwach kombatanckich można znaleźć podobne sposoby wykorzystania pól bitewnych jako „piekielnego pejzażu”, w którym człowieczeństwo zanika, a żołnierze są zmuszani do znoszenia męki ostrzału artyleryjskiego, pocisków gazowych i karabinowych, jak również niekompetencji lub obojętności elit politycznych i wojskowych. W australijskiej powieści Barbed Wire and Roses z 2007 roku, autorstwa Petera Yeldhama, historię „złotej młodzieży" wysłanej do walki w skrwawionych okopach Gallipoli i Sommy przytacza się za pośrednictwem odkrytych przez wnuka pamiętników weterana $^{33}$. Ta rodzinna więź ukazuje wciąż żywą traumę konfliktu w chwili, gdy potomek rodziny podróżuje do Francji, aby odkryć tajemnicę zniknięcia dziadka. W powieści pola bitew okazują się perwersyjnym tłem dla przypadkowego zabijania, miejscem, gdzie przerażające sceny walki sprawiają,

Tamże, s. 26. 
że młodzi ludzie stają się ofiarami nerwicy frontowej, niepotrafiącymi zrozumieć swoich działań czy miejsca, jakie zajmują w teatrze wojny. Takie podejście zmniejsza moralną odpowiedzialność żołnierzy w czasie wojny i podkreśla ich niewinność w kontekście pełnionej przez nich roli militarnej: „Czymś ekscytującym było ruszyć wreszcie w drogę, ale stanowiliśmy zbieraninę skończonych żółtodziobów. Nie mieliśmy pojęcia o piekle, które na nas czekało. Nawet gdybyśmy wiedzieli, co można by z nim zrobić?"34.

W brytyjskiej powieści z 1998 roku Angels of Mercy Lyn Andrews życie kobiet i mężczyzn zmienia się nieodwracalnie za sprawą doświadczeń na froncie, które ze względu na obserwowane barbarzyństwo doprowadzą ich do wewnętrznej przemiany. Powieść The First Casualty Brytyjczyka Bena Eltona z 2005 roku w zbliżony sposób podkreśla przemianę jednostki na polu bitwy, ujawniającym w gwałtownej wymianie kul i pocisków artyleryjskich „prawdę" o cierpieniu ludzkim³ ${ }^{35}$. Bohater tej książki odrzuca dążenie do wojny z pobudek moralnych, zmuszony jest jednak do podejmowania wypraw na front, aby zbadać sprawę zabójstwa znanego nacjonalistycznego poety. Odkrywa, że ów artysta, oficjalnie ulubieniec establishmentu, miał potępić konflikt za jego absurdalne marnotrawstwo życia. Właśnie temat "prawdy" wojny, straszliwych pól bitewnych, które odczłowieczają jednostki, powtarza się w całej powieści: „Spójrz na nas, jesteśmy owcami, ot co. Owce na cholerną rzeź. Nie możemy wygrać tej wojny, nie my, biedna, cholerna piechota. Siedzimy po prostu w nadziei, że zarobimy jakiś strzał, tylko po to, żeby jako kaleki pokuśtykać do domu, wdzięczni, żeśmy nie pomarli"36. Obecność pola bitewnego, które nawiedza umysły żołnierzy, ich rodzin i powracających do domu weteranów, jest także elementem pojawiającym się w kanadyjskiej powieści Broken Ground (1998) Jacka Hodginsa ${ }^{37}$. Zobrazowany w niej teatr działań wojennych na froncie zachodnim staje się punktem odniesienia dla kształtującego się „narodowego charakteru” Kanadyjczyków, gdy grupa byłych żołnierzy osiedla się wśród ponurych, opustoszałych krajobrazów na wyspie Vancouver. Służba, poświęcenie i wysiłek żołnierzy znajdują odzwierciedlenie w tworzeniu wspólnoty, pożar lasu natomiast, grożący pochłonięciem ich dzieła, przywołuje koszmarne sceny bitwy na wzgórzu Vimy.

\footnotetext{
34 Tamże, s. 1.

35 B. Elton The First Casualty, Bantam Press, London 2005.

36 L. Andrews Angels of Mercy, Headline, London 1998, s. 43.

37 J. Hodgins Broken Ground, McClelland and Stewart, Toronto 1998.
} 
W kolejnych powieściach autorów kanadyjskich, takich jak The Stone Carvers Jane Urquhart (2001) lub Deafening Frances Itani (2003), pola bitew tworzą żołnierski krajobraz cierpienia ${ }^{38}$, podkreślając tragedię i traumę wojny zarówno w odniesieniu do tych, którzy służyli na froncie, jak i ich rodzin. Krajobraz wojenny nie wysuwa się jednak w tych utworach na pierwszy plan, a staje się raczej nawiedzającym bohaterów widmem. Taki sposób ujęcia konfliktu uwypukla wagę I wojny światowej w kanadyjskiej pamięci narodowej, jej poruszającą, uporczywą obecność, która definiuje miejsce, przynależność i tożsamośćc ${ }^{39}$. Pola bitew tworzą scenę męczeństwa, gdzie przetrwanie wojny kształtuje po dziś dzień tożsamość walczących i tych, którzy pozostali w domu, a także ich potomków. Jest to kluczowa cecha australijskiej powieści Tea-Tree Passage (2001) autorstwa Robyn Burrows: spuścizna Wielkiej Wojny - roztaczający się wszędzie horror pól bitewnych - rzuca długi cień na kilka pokoleń mieszkańców południowo-zachodniej Australiii ${ }^{40}$. Obecność pejzażu wojennego, jego wpływ na kolejne pokolenia i trwanie w umysłach przyszłych generacji zostały szczegółowo opisane w powieści brytyjskiego powieściopisarza Adama Thorpe'a Nineteen Twenty-One (2001) ${ }^{41}$. Utwór ten nie odnosi się jednak do kwestii ciągłości traumy i jej wspólnego odczuwania, a do niemożliwości zrozumienia takiego wydarzenia przez potomków pokolenia wojennego. W opowieści tej protagonista to początkujący pisarz: wojna wprawdzie go omija, ale stara się zrozumieć prawdę i pojąć konflikt już po zakończeniu wojny, stawiając się obok tych, którzy w niej ucierpieli. Przeprowadzając wywiady ze straumatyzowanymi żołnierzami i odwiedzając miejsca bitew, gdzie można oglądać ludzkie szczątki i materialne pozostałości wojny, główny bohater zdaje sobie sprawę z niemożności opisania Armagedonu; takie jest właśnie cierpienie tych, którzy zamieszkiwali pola konfliktów.

W ten sposób opuszczone pola bitewne stają się narzędziem kulturowym, pozwalającym podkreślać znaczenie i wyjątkowość traumy I wojny światowej. Dla australijskich, brytyjskich i kanadyjskich powieściopisarzy krajobraz wojenny tworzy scenę tożsamości, ukształtowaną przez cierpienia żołnierzy; by znaleźć uzasadnienie dla charakteru i tożsamości jednostek, odwiedza się

\footnotetext{
38 J. Urquhart The Stone Carvers, McClelland and Stewart, Toronto 2001; F. Itani Deafening, Harper Collins, Toronto 2003. 
ponownie pola bitew, czy to osobiście, czy też za sprawą jakiejś widmowej obecności. „Prawda” wojny, przejawiająca się w okropnościach i brutalności doświadczanej przez jej uczestników, obsadza te jednostki w roli „ofiar” konfliktu. Poczucie bycia ofiarą podkreśla traumę wojny, która ciągle trwa, jest odczuwana i doświadczana przez kolejne pokolenia. Dlatego, chociaż wiele z tych powieści zajmuje się wydarzeniami pojawiającymi się po ustaniu działań wojennych w listopadzie 1918 roku, I wojna światowa wcale się w nich nie kończy. Rzeczywiście, pojawienie się zdewastowanego krajobrazu wojennego jako środka pozwalającego nawiedzać społeczeństwa dowodzi potrzeby wykazania, że chodzi o historyczną traumę, z którą nadal trzeba żyć.

\section{Perspektywa świadka}

Pozamedialna funkcja wszystkich tych powieści, programów telewizyjnych i filmów polega zatem na utrzymaniu we współczesnym społeczeństwie poczucia traumy związanej z I wojną światową. Traumy tej nie przywołuje się dlatego, że jest to w jakimś sensie historia „łatwiejsza” lub bardziej „dostępna”. W istocie, przywołane wcześniej media odzwierciedlają sposób, w jaki przeszłość nadal dotyczy teraźniejszości. Utrzymują one, a nie wytwarzają, owo poczucie traumy. Zamiast przyjąć założenie, że łatwowierni odbiorcy bezmyślnie konsumują te środki przekazu, być może właściwiej byłoby uznać, że tego rodzaju materiały tworzą pewną ramę lub soczewkę, przez którą można oglądać przeszłośćc ${ }^{42}$. Takie formy kultury umożliwiają współczesnym pełnienie roli świadków historycznej traumy, przenoszenie ciężaru pamięci w teraźniejszość. Model świadka nadaje się zatem do badań nad pamięcią I wojny światowej. Za sprawą świadectwa pamięć ta jest przekazywana jednostkom, grupom i ogółowi społeczeństwa w oczekiwaniu, że z kolei ich świadectwo podtrzyma "prawdę" tej historii. Perspektywę tego rodzaju propaguje się w kulturowych reprezentacjach I wojny światowej w zawoalowany sposób, ale też całkiem otwarcie. Na przykład brytyjska powieściopisarka Pat Barker zgłębia tę kwestię bez żadnych osłonek w Another World (1998) ${ }^{43}$. Powieść opisuje ostatnie dni życia weterana, który powoli się starzeje, a jego pamięć o wojnie zaczyna przenikać do teraźniejszości. Gdy stary żołnierz przeżywa raz jeszcze grozę i traumę wojenną, rodzina, która obserwuje jego ostatnie chwile życia, zaczyna pojmować, co umierający

\footnotetext{
42 J. Wertsch Voices, s. 12.

P. Barker Another World, Viking Press, London 1998.
} 
znaczy dla tych, których pozostawia. W rezultacie powieść przedstawia szeroką pamięć konfliktu krajów biorących udział w wojnie, ale w małej skali. Gdy umierają ostatni weterani, I wojna światowa wykracza poza „żywą pamięć”, zapewniając współczesnemu społeczeństwu możliwość podtrzymywania wspomnień o niej dzięki przyjęciu roli świadka wobec przeszłości.

Taki zwrot w refleksji prezentują nie tylko powieści, ale i szerszy zbiór medialnych reprezentacji wojny. Przykładu zbliżonego podejścia dostarcza ramówka stacji $\mathrm{ABC}$ przygotowana na przypadającą w 2005 roku rocznicę kampanii dardanelskiej. W Revealing Gallipoli (reż. Wain Fimeri, Australian Broadcasting Corporation, 2005) ${ }^{44}$ współczesny widz otrzymuje szczegółową ocenę prawdopodobnie najbardziej hołubionej w Australii sceny zbrojnej z tego okresu. Opierając się na precyzyjnej grafice komputerowej i relacjach żołnierzy, program serwuje współczesnemu odbiorcy następujący osąd „horroru” wojny: „Relacje z pierwszej ręki mówią widzom, jak wyglądało, pachniało i dawało się odczuwać Gallipoli, a niezwykłe obrazy archiwalne w 3D ożywiają te sceny. Ruchome mapy ilustrują nieprzyjazny teren, z którym musieli radzić sobie żołnierze, i objaśniają strategie stojące za przebiegiem konfliktu" (Revealing Gallipoli). Wspomniany film dokumentalny pozwolił widzom stać się świadkami przeszłości, dając dowód znaczenia konfliktu i jego miejsca w australijskim społeczeństwie. Z kolei Canada: A People's History (reż. Serges Turbide, Canadian Broadcasting Corporation, 2000), wyprodukowany przez CBC telewizyjny film dokumentalny o przełomowych momentach w historii, również umożliwił widzom przyjęcie roli świadków przeszłości. Ten złożony z wielu części program opowiada o historii Kanady, a wydarzenia z czasu I wojny światowej doczekały się odrębnego odcinka, zatytułowanego „Próba ognia”. W ramach programu po raz kolejny wykorzystano współczesne listy i pamiętniki, aby zademonstrować znaczenie wojny dla tych, którzy walczyli, dla tych, co zostali w domu, oraz dla obecnego pokolenia Kanadyjczyków: „Groza, odwaga i poświęcenie właściwe wojnie prowadzonej w okopach towarzyszą wielkim bitwom toczonym przez Kanadę: nad Sommą, pod Ypres, Vimy, Courcelette i Passchendaele"45.

Perspektywa świadka jest nader istotna, ponieważ pozwala na kontynuację traumy I wojny światowej. To właśnie takie poczucie traumy ma wartość polityczną, symboliczną i społeczną; dostarcza sposobu na utożsamienie się

\footnotetext{
44 Revealing Gallipoli, ABC http://www.abc.net.au/tv/guide/netw/200504/programs/ZY7664A001D24042005T193000.html (23.10.2005). 
i gwarantuje, że pamięć o konflikcie nie przemieni się w historię. Podtrzymywanie traumatycznej pamięci konfliktu jako pamięci bieżącej, odczuwanej i doświadczanej ma kluczowe znaczenie dla potwierdzenia jej symbolicznej wartości. Jest to kwestia pomijana przez historyków-rewizjonistów, którzy starają się krytykować popularną pamięć o wojnie jako niedokładną pod względem historycznym: „Nie chodzi o to, by zapamiętać przeszłe traumy tak dokładnie, jak to tylko możliwe: taka "dokumentacja” jest a priori fałszywa, przekształca traumę w neutralny, obiektywny fakt, podczas gdy istotą traumy jest właśnie to, że jest zbyt straszna, aby ją zapamiętać, zintegrować z naszym symbolicznym wszechświatem" ${ }^{\text {"46 }}$. W tym kontekście uwypuklona zostaje przeprowadzona przez Nietzschego krytyka zachodnich systemów kulturowych, które opierają się na przewlekłym poczuciu traumy; jeśli coś ma pozostać w pamięci, musi zostać w niej wypalone, nigdy nie może przestać bolećc ${ }^{\prime 7}$.

\section{Podsumowanie}

O potocznej pamięci I wojny światowej w Australii, Wielkiej Brytanii i Kanadzie często mówi się z lekceważeniem, a niektórzy komentatorzy przyjmują, że popularne obrazy „szczurów, gazu, błota i krwi” na polach bitewnych powstają na podstawie uproszczonej akceptacji powieści, filmów i programów telewizyjnych, które obrazują konflikt. Aby podważyć takie przekonanie, badania potocznej pamięci o wojnie 1914-1918 mogą pomóc oszacować, w jaki sposób pamięć funkcjonuje w tych społeczeństwach, które czczą ją nadal. W takim ujęciu pamięć wojny traktuje się nie jako przejaw biernej konsumpcji, lecz czynny wybór dokonywany przez jednostki, grupy i społeczności, które pragną pamiętać w określony sposób, ponieważ ma to swój cel i przeznaczenie. Pamięć potoczna uruchamia się, by afirmować kwestie tożsamości i miejsca w ramach tych społeczeństw. Co za tym idzie, kulturowe reprezentacje konfliktu można poddać ocenie, by zademonstrować, w jaki sposób media podtrzymują pamięć potoczną i jak się na niej koncentrują, a nie jak ją konstruują. Efekt ten osiąga się poprzez ilustrację traumy wojennej. Dzięki obrazom cierpiących żołnierzy, zdewastowanych krajobrazów pól bitewnych czy włączeniu perspektywy świadka, podtrzymuje się poczucie traumy kulturowej. Umożliwia to współczesnym doświadczanie i odczuwanie

\footnotetext{
46 S. Žižek For They Know Not What They Do: Enjoyment As a Political Factor Verso, London 2002, S. 272.

47 F. NietzscheZ Zgenealogii moralności. Pismo polemiczne, przeł. L. Staff, Zielona Sowa, Kraków 2006.
} 
wydarzeń z okresu I wojny światowej w kategoriach ciągłego niepokoju. Próby reinterpretacji potocznej pamięci o konflikcie nie uwzględniają tego, że trauma wojny ma dla ogółu totemiczną wartość. Dlatego, mimo odejścia ostatnich weteranów i coraz większego dystansu dzielącego wydarzenia z lat 1914-1918 od chwili obecnej, wojna trwa nadal.

Przełożyli Tomasz Bilczewski i Anna Kowalcze-Pawlik

\section{Abstract}

\section{Ross J. Wilson}

CHICHESTER UNIVERSITY

It Still Goes On: Trauma and the Memory of the First World War

Wilson describes the basic elements of representations of World War I: the suffering of soldiers, devastated battle grounds and the perspective of the witness. Referring to current research on trauma in the context of World War I he thematizes the stereotypical ways in which the Great War is commonly remembered - ways that exclude communication and maintain a sense of trauma. Wilson evaluates recent novels as well as film and television productions in order to analyse contemporary representations of a traumatic past impacting identity. His analysis focuses on cultural texts produced after the eightieth anniversary of the end of the Great War and cultural representations of the war that perpetuate trauma in Australia, Great Britain and Canada, constituting their citizens' identities. Wilson treats these phenomena as a product of the capitalist entertainment industry and as an expression of the general longing to maintain traditional ideas about the past.

\section{Keywords}

memory and World War I; memory and popular culture; trauma studies; war in popular culture 